\title{
DEVIDO PROCESSO LEGAL E TRABALHADORES MIGRANTES NO BRASIL
}

DUE LEGAL PROCESS AND MIGRANT WORKERS IN BRAZIL

\author{
Jorge Luís Mialhe ${ }^{1}$ \\ Carolina Marzola Hirata Zedes ${ }^{2}$
}

Resumo: No presente artigo utiliza-se o método dedutivo-normativo para tratar dos migrantes internacionais e seu acesso à justiça. Destaca-se a mobilidade do trabalhador migrante internacional e sua situação de vulnerabilidade, o que faz com que as lesões trabalhistas envolvendo os migrantes possam ocorrer com maior intensidade e frequência, mormente diante da relação assimétrica do contrato de trabalho, razão pela qual the deve ser garantido o acesso à justiça, assegurando-se seus direitos fundamentais de cunho processual, pois o estrangeiro não deve ser tratado de forma hostil. No texto abordam-se os principais óbices processuais para o acesso do trabalhador migrante à Justiça do Trabalho, como a forma de acionamento, o idioma, os custos do processo, o tempo de tramitação e a necessidade de prática pessoal de determinados atos processuais, bem como os mecanismos existentes na ordem jurídica para superá-los, como a cooperação jurídica internacional, a disponibilização de intérprete, a assistência judiciária gratuita e a modulação dos atos processuais, aplicando-se o devido processo legal.

Palavras-chave: Trabalhador. Migrante internacional. Acesso à justiça. Devido processo legal.

\begin{abstract}
This article used the deductive-normative method to treat international migrants and their access to justice. It emphasizes the mobility of the international migrant workers and their vulnerability situation, which makes that labor injuries involving the migrants occur with greater intensity and frequency, especially in the asymmetric relation of the work contract, and this is the reason why the access to justice must be guaranteed to them, ensuring their fundamental rights with procedural grounds, because the foreigner should not be treated in a hostile manner. The text approaches the procedural obstacles to the access of the migrant to the Labor Court, such as the way of action, the language, the costs of the process, the proceeding time, and the need for personal practice of procedures acts, as well as the existing mechanisms in the legal order to overcome them, such as the international legal cooperation, the availability of interpreters, free legal aid, and modulation of procedural acts, applying the due legal process.
\end{abstract}

Keywords: Worker. International migrant. Access to justice. Due legal process.

\footnotetext{
1 Pós-doutor nas Universidades de Paris III - "Sorbonne-Nouvelle" e de Limoges; Doutor pela Universidade de São Paulo; Professor no Curso de Mestrado em Direito da Universidade Metodista de Piracicaba; Rodovia do açúcar, Km 156, Taquaral, Piracicaba, São Paulo, Brasil; profmialhe@hotmail.com; https://orcid.org/0000-0002-0744-796X

2 Especialista em Direito Constitucional pela Universidade do Sul de Santa Catarina; mestranda em Direitos Fundamentais Coletivos e Difusos pela Universidade Metodista de Piracicaba; carolmhirata@yahoo.com.br; https://orcid.org/0000-00034565-7420
} 


\section{Introdução}

A Organização Internacional para Migrações (OIM) é o organismo das Nações Unidas que se ocupa dos migrantes e das questões relacionadas com a migração e, em coordenação com os Estados envolvidos, ocupa-se dos migrantes que requerem serviços de migração no plano internacional. Essa organização internacional define migrante como

$$
\begin{aligned}
& \text { qualquer pessoa que se desloca ou se deslocou através de uma fronteira } \\
& \text { internacional ou dentro de um país, fora do seu lugar habitual de residência } \\
& \text { independentemente: 1) da sua situação jurídica; 2) do caráter voluntario ou } \\
& \text { involuntário do deslocamento; 3) das causas do deslocamento; ou 4) da duração da } \\
& \text { sua estadia. (ORGANIZAÇÃO INTERNACIONAL PARA MIGRAÇÕES, 2018). }
\end{aligned}
$$

Portanto, essa definição abrange os migrantes internacionais de todo tipo, além dos refugiados e deslocados ambientais. De acordo com dados do World Migration Report 2018, estima-se que existam mais de 244 milhões de migrantes internacionais, ou seja, 3,3\% da população mundial (ORGANIZAÇÃO INTERNACIONAL PARA MIGRAÇÕES, 2017, p. 13).

O Brasil não permanece alheio a essa realidade. Segundo informações do Alto Comissariado das Nação Unidas para Refugiados (ACNUR) (2017), são 8.863 refugiados no Brasil, incluindo reassentados (ALTO COMISSARIADO DAS NAÇÕES UNIDAS PARA REFUGIADOS, 2013), além de 80.000 haitianos com vistos humanitários (BRASIL, 2016), concedidos pelo Conselho Nacional da Imigração.

Conforme o art. $2^{\circ}$. da Convenção Internacional sobre a Proteção dos Direitos de Todos os Trabalhadores Migrantes e dos Membros das suas Famílias, adotada pela Resolução n. 45/158, de 18 de dezembro de 1990, da Assembleia-Geral das Nações Unidas, que entrou em vigor a 01 de julho de 2003 (não foi assinada pelo Brasil): "trabalhador migrante designa a pessoa que vai exercer, exerce ou exerceu uma atividade remunerada num Estado de que não é nacional." (ORGANIZAÇÃO DAS NAÇÕES UNIDAS, 1990).

Assim, migrante internacional constitui vocábulo de acepção ampla que identifica asilados, refugiados e migrantes propriamente ditos, pelos mais diversos motivos que ensejam a movimentação de pessoas, como motivos econômicos ou ambientais, sendo que a marca distintiva principal entre os migrantes propriamente ditos e, de outro lado, asilados e refugiados, é a voluntariedade da movimentação, presente nos primeiros e ausente nos últimos.

Conforme a lição de Kant (2008, p. 37), devem ser garantidos o "direito à hospitalidade" ao migrante internacional e o direito de o estrangeiro não ser tratado de forma hostil, como inimigo (hostis) e, conforme Bauman (2017, p. 74), é imperiosa "a substituição da hostilidade pela hospitalidade." Para tanto, é essencial que ocorra a integração local do migrante, sendo esse um processo complexo que irá abranger múltiplos fatores, dentre eles os socioeconômicos, os culturais e os políticos (MIALHE, 2017, p. 54). 
Esses migrantes internacionais (em sentido amplo), quando exercem atividade remunerada, não raro necessitam se valer de mecanismos processuais para terem seus direitos trabalhistas assegurados, acionando a Justiça do Trabalho. A análise dos óbices processuais para a defesa dos seus direitos e interesses, encontrados nos ritos estruturados pela Consolidação das Leis do Trabalho, bem como a maneira de superá-los constituem o ponto central deste estudo.

\section{0 acesso à justiça e a vulnerabilidade acentuada do trabalhador migrante}

Consoante art. $5^{\circ}$, inciso XXXV, da Constituição Federal, "a lei não excluirá da apreciação do Poder Judiciário lesão ou ameaça a direito." O dispositivo em tela representa a positivação do direito de acesso à justiça como direito fundamental de titularidade de todas as pessoas naturais e jurídicas (inclusive entes despersonalizados). Cuida-se de direito de cunho processual e, portanto, instrumental à tutela dos direitos fundamentais materiais. Como explica Marinoni (2012, p. 208):

O direito de ação cobre a multifuncionalidade dos direitos fundamentais, ou seja, pode ser utilizado conforme as necessidades funcionais dos direitos fundamentais. Portanto, é um direito que se coloca sobre todas essas funções e, na verdade, sobre todos os direitos fundamentais materiais. É que os direitos fundamentais materiais dependem, em termos de efetividade, do direito de ação.

Em sua concepção mais moderna, o direito de ação requer não somente a retirada de óbices jurídicos e materiais para o acesso à justiça, por meio da provocação formal do Poder Judiciário, mas também que a tutela jurisdicional prestada através do processo seja efetiva e tempestiva, protegendo adequadamente o direito material objeto de tutela. Em outras palavras, o direito de acesso à justiça não se compraz à mera virtualidade de propositura de uma ação, mas exige que a tutela jurisdicional seja entregue em sua plenitude.

Na mesma linha, a Lei de Migração ${ }^{3}$ assegura ao trabalhador migrante o acesso à justiça e à assistência jurídica integral gratuita:

Art. $4^{\circ}$ Ao migrante é garantida no território nacional, em condição de igualdade com os nacionais, a inviolabilidade do direito à vida, à liberdade, à igualdade, à segurança e à propriedade, bem como são assegurados:

$[\ldots]$

IX - amplo acesso à justiça e à assistência jurídica integral gratuita aos que comprovarem insuficiência de recursos; [...] (BRASIL, 2017).

\footnotetext{
3 A nova Lei de Migração, Lei n. 13.445, foi sancionada em maio de 2017 e regulamentada pelo Decreto n. 9.199 , de 20 de novembro de 2017. A Lei garante ao migrante, em condição de igualdade com os nacionais, a inviolabilidade do direito à vida, à liberdade, à igualdade, à segurança e à propriedade. Também, institui o visto temporário para acolhida humanitária, a ser concedido ao apátrida ou ao nacional de país que, entre outras possibilidades, encontre-se em situação de grave e generalizada violação de direitos humanos - situação que possibilita o reconhecimento da condição de refugiado, segundo a Lei n. 9.474, art. $1^{\circ}$, III.
} 
Tratando especificamente dos migrantes internacionais, não bastasse a incidência do regramento constitucional, existem normas internacionais específicas que lhe asseguram o acesso à justiça, em caso de violação de seus direitos. É o que preceitua a Convenção 97 da OIT:

1. Todo Membro para o qual se ache em vigor a presente convenção se obriga a aplicar aos integrantes que se encontrem legalmente em seu território, sem discriminação de nacionalidade, raça, religião ou sexo, um tratamento que não seja inferior ao aplicado a seus próprios nacionais com relação aos seguintes assuntos: $[\ldots]$

d) as ações judiciais relativas às questões mencionadas na seguinte convenção. (BRASIL, 1966).

No mesmo sentido, o art. 16 da Convenção sobre o Estatuto dos Refugiados (1951):

1. Qualquer refugiado terá, no território dos Estados Contratantes, livre e fácil acesso aos tribunais.

2. No Estado Contratante em que tem sua residência habitual, qualquer refugiado gozará do mesmo tratamento que um nacional, no que concerne ao acesso aos tribunais, inclusive a assistência judiciária e a isenção da cautio judicatum solvi.

3. Nos Estados Contratantes outros que não o que tem sua residência habitual, e no que concerne às questões mencionadas no parágrafo 2 , qualquer refugiado gozará do mesmo tratamento que um nacional do país no qual tem sua residência habitual. (ALTO COMISSARIADO DAS NAÇÕES UNIDAS PARA REFUGIADOS, 1951).

A Convenção n. 143 da OIT (art. 9) e a Convenção Internacional sobre a Proteção dos Direitos de Todos os Trabalhadores Migrantes e dos Membros das suas Famílias (art. 54) (ambas não ratificadas pelo Brasil) também seguem a mesma linha, respectivamente:

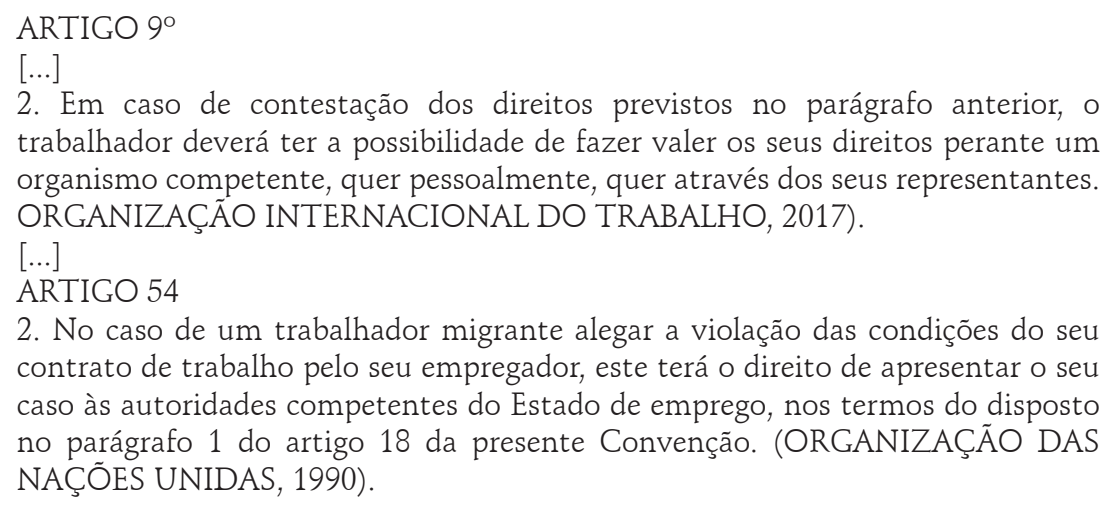
trabalhador deverá ter a possibilidade de fazer valer os seus direitos perante um organismo competente, quer pessoalmente, quer através dos seus representantes. ORGANIZAÇÃO INTERNACIONAL DO TRABALHO, 2017).

$[\ldots]$ ARTIGO 54

2. No caso de um trabalhador migrante alegar a violação das condições do seu contrato de trabalho pelo seu empregador, este terá o direito de apresentar o seu caso às autoridades competentes do Estado de emprego, nos termos do disposto no parágrafo 1 do artigo 18 da presente Convenção. (ORGANIZAÇÃO DAS NAÇÕES UNIDAS, 1990).

Em que pese ser formalmente garantido ao trabalhador migrante o direito de integração e de informação sobre seus direitos, não se pode olvidar sua condição de vulnerabilidade, decorrente de um certo isolamento em razão do idioma e da cultura diversas da população local e da usual carência de recursos financeiros (razão primordial de seu deslocamento voluntário).

Essa vulnerabilidade é acentuada quando o migrante internacional se insere em uma relação jurídica eminentemente vertical como a relação de emprego. Se o contrato de trabalho, em decorrência de sua própria conformação estrutural de conter em um dos polos uma parte hipossuficiente (o 
trabalhador), já constitui campo fértil para violações aos direitos trabalhistas, quando se insere nessa relação o trabalhador migrante internacional, a situação se agrava e se produzem as condições fáticas para quadros de superexploração, mormente quando o migrante internacional não preencheu os requisitos de ingresso no país (migrante irregular). ${ }^{4}$

Pertinente trazer à reflexão o pensamento de Standing (2013), que explica a diferença entre cidadãos e habitantes, inserindo nessa última categoria os migrantes, em diferentes níveis, conforme passem a adquirir direitos. Para o autor, a migração atual não corresponde à assimilação de uma nova cidadania, mas, sim, à formação de um proletariado pronto para ser descartado, sem os benefícios do Estado ou da empresa, como meros titulares de direitos que foram concedidos discricionariamente pelo Estado, o que corresponde à concepção histórica de "habitante" na Idade Média, na Inglaterra e em outros países europeus. Como destaca o autor:

No entanto, o conceito de "habitante" é útil para delinear o que as pessoas podem ou não fazer na sociedade. $O$ espectro começa com os solicitantes de asilo, que praticamente não têm direito algum. À medida que seu número cresce, os governos dificultam mais suas vidas. Muitas vezes eles são humilhados e tratados como se fossem criminosos. Aqueles que são capazes podem tentar sobreviver levando uma existência precariada. Muitos simplesmente padecem, vendo suas vidas definharem.

Em seguida, estão os migrantes em situação irregular, que têm direitos civis como seres humanos, mas não têm os direitos econômicos, sociais ou políticos. Normalmente, não têm nenhuma alternativa para ganhar a via no precariado, com muitos deles fazendo isso na economia subterrânea. Nos Estados Unidos, os milhões de migrantes em situação irregular não têm direito de trabalhar por salário, mas são contratados de qualquer forma. Vivem com a ameaça da deportação e sem direito à proteção social, tais como os benefícios de desemprego. $\mathrm{Na}$ Espanha, cogita-se que milhões de migrantes não regularizados explicam a enorme economia subterrânea no país. É provável que a história seja semelhante na maioria dos países.

Depois há aqueles com o direito de residência temporária, mas que têm restrições do que podem fazer legalmente de acordo com a situação de seu visto. Eles podem ter alguns direitos sociais, como o direito aos benefícios da empresa e do Estado, e talvez o direito de pertencer a organizações econômicas, tais como sindicatos ou associações empresariais. Mas têm direitos limitados ou nenhum direito à mobilidade socioeconômica e nenhum direito político, o que lhes dá pouca oportunidade de se integrarem à sociedade local. Eles são os "habitantes" clássicos. Mais adiante no espectro estão os "habitantes" que têm direito à residência de longo prazo e são formalmente autorizados a procurar empregos de sua preferência. Eles podem ser relativamente seguros, porém enfrentam limitações estruturais nos direitos econômicos e sociais, por exemplo, se possuem qualificações que não são reconhecidas no país. (STANDING, 2013, p. 147).

Justamente em razão desse quadro, no qual estão presentes maiores possibilidades de violações aos direitos dos trabalhadores migrantes, é que ganha importância assegurar mecanismos processuais adequados, de acionamento e de tramitação, capazes de responder às especificidades

\footnotetext{
4 Conforme Pardi (2015, p. 57), "No Brasil não se deve utilizar o termo imigrante ilegal, mas sim imigrante irregular, já que aqui não se criminaliza o fato de um estrangeiro ingressar ou permanecer no país ao arrepio da Lei de Migração. Trata-se, pois, de uma questão meramente administrativa."
} 
requeridas para a tutela dos direitos dos trabalhadores migrantes internacionais, considerando, especialmente, sua vulnerabilidade acentuada e sua mobilidade global, em contraponto aos recursos necessários para defesa dos seus interesses, ao tempo de tramitação do processo e à necessidade da prática pessoal de determinados atos processuais na Justiça do Trabalho.

\section{2 Óbices processuais na Justiça do Trabalho}

Nesta parte do artigo serão abordadas questões relativas aos direitos processuais fundamentais assegurados aos trabalhadores migrantes e os principais óbices processuais de acesso à justiça pelo trabalhador migrante: a barreira do idioma no âmbito do processo e os seus custos, a prática pessoal de atos processuais e o tempo de tramitação do processo.

\subsection{Direitos processuais fundamentais assegurados aos trabalhadores migrantes}

A análise de questões processuais que envolvem o trabalhador migrante deve ser precedida de um entendimento acerca das particularidades da situação do migrante internacional.

Sem um arcabouço prévio, tanto jurídico-normativo quanto fático, relativos às especificidades do tema, não se pode compreender as barreiras processuais atualmente existentes e que constituem óbices para o acesso à justiça pelo migrante internacional. Acesso à justiça entendido não como a mera virtualidade de ingresso com uma ação, mas como a possibilidade concreta de defender seus direitos e interesses e de influenciar a decisão final do juiz. Afinal, o migrante internacional também é titular dos direitos e garantias fundamentais de cunho processual, como contraditório, ampla defesa, devido processo legal, vedação ao uso da prova ilícita, motivação das decisões judiciais, razoável duração do processo, entre outros. Como previsto no art. $5^{\circ}$, caput, da Constituição da República, os direitos fundamentais são extensíveis aos brasileiros e aos estrangeiros residentes no País.

E mais: a despeito da textualidade do dispositivo, a doutrina destaca que devem ser assegurados os direitos fundamentais inclusive aos estrangeiros não residentes, isso porque o Brasil se rege, nas suas relações internacionais, pela prevalência dos direitos humanos. Explica Sarlet (2007, p. 232-233):

Nesse contexto, há que se invocar o princípio da universalidade, que, fortemente ancorado no princípio da dignidade da pessoa humana, evidentemente não permite a exclusão generalizada de estrangeiros não residentes da titularidade de direitos, sendo correta a tese de que pelo menos todos os direitos diretamente fundados na dignidade da pessoa humana são extensivos aos estrangeiros. Também aqui assume relevo o que poderia ser chamado de função interpretativa do princípio da universalidade, que, na dúvida, estabelece uma presunção de que a titularidade de um direito fundamental é atribuída a todas as pessoas.

$[\ldots]$ 
Ainda nesse contexto, por se cuidar de aspecto relativo aos estrangeiros de um modo geral, é preciso destacar que eventual ilegalidade da permanência no Brasil por si só não afasta a titularidade de direitos fundamentais, embora não impeça (respeitados os direitos, inclusive o do devido processo legal), eventuais sanções, incluindo a deportação ou mesmo extradição.

No mesmo sentido, já se pronunciou o Supremo Tribunal Federal:

o fato de o paciente ostentar a condição jurídica de estrangeiro e de não possuir domicílio no Brasil não the inibe, só por si, o acesso aos instrumentos processuais de tutela da liberdade nem the subtrai, por tais razões, o direito de ver respeitadas, pelo Poder Público, as prerrogativas de ordem jurídica e as garantias de indole constitucional que o ordenamento positivo brasileiro confere e assegura a qualquer pessoa que sofra persecução penal instaurada pelo Estado. (SÂO PAULO, 2008).

Seguindo a linha do doutrinador e da Corte Suprema, mesmo a situação de ilegalidade no ingresso e permanência no país não deve impedir ou cercear o ingresso com a ação cabível em caso de sonegação dos direitos trabalhistas, pois, repise-se, trata-se de um direito fundamental incondicionado, embora seja forçoso reconhecer que, nessa hipótese, por condicionantes fáticos, raramente o trabalhador migrante irá procurar a Justiça para a defesa dos seus interesses, temendo a deportação. Há, todavia, e como será visto adiante, a possibilidade de acionamento do Poder Judiciário, via cooperação internacional.

Nas palavras de Bobbio (1992, p. 25):

Com efeito, o problema que temos diante de nós não é filosófico, mas jurídico e, num sentido mais amplo, político. Não se trata de saber quais e quantos são esses direitos qual é a sua natureza e seu fundamento, se são direitos naturais ou históricos, absolutos ou relativos, mas sim qual é o modo mais seguro para garantilos, para impedir que, apesar das solenes declarações, eles sejam continuamente violados.

A recente Lei de Migração (Lei n. 13.445/2017), no caput do seu art. 4º, seguindo a linha de universalidade dos direitos humanos, prevê textualmente que ao migrante internacional é garantida, no território nacional, "em condição de igualdade com os nacionais, a inviolabilidade do direito à vida, à liberdade, à igualdade, à segurança e à propriedade, bem como são assegurados: I - direitos e liberdades civis, sociais, culturais e econômicos." (BRASIL, 2017).

Por seu turno, a Convenção Internacional sobre a Proteção dos Direitos de Todos os Trabalhadores Migrantes e dos Membros das suas Famílias (1990), embora não assinada e não ratificada pelo Brasil, em seu art. 18, enumera os direitos processuais assegurados ao migrante quando acusado de um crime.5 Os mesmos direitos podem ser analogicamente aplicáveis às áreas cível e trabalhista, quando cabíveis:

\footnotetext{
5 O Itamaraty, na Mensagem 696, de 13 de dezembro de 2010, recomendou ao Congresso Nacional "que, em caso de adesão por parte da República Federativa do Brasil, devem ser opostas reservas ao artigo $18, \mathbb{\$} 3^{\circ}$, alínea g. [...] Embora o ordenamento jurídico brasileiro garanta o direito de não se incriminar, entende-se que qualquer pessoa tem o dever de servir como
} 
1. Os trabalhadores migrantes e os membros das suas famílias têm os mesmos direitos, perante os tribunais, que os nacionais do Estado interessado. Eles têm o direito a que a sua causa seja equitativa e publicamente julgada por um tribunal competente, independente e imparcial, instituído por lei, que decidirá dos seus direitos e obrigações de caráter civil ou das razões de qualquer acusação em matéria penal contra si formulada.

2. O trabalhador migrante ou membro da sua família suspeito ou acusado da prática de um crime presumir-se-á inocente até que a sua culpabilidade tenha sido legalmente estabelecida.

3. O trabalhador migrante ou membro da sua família acusado de ter infringido a lei penal tem, no mínimo, direito às garantias seguintes: a) A ser informado prontamente, numa língua que compreenda e pormenorizadamente, da natureza e dos motivos das acusações formuladas contra si; b) A dispor do tempo e dos meios necessários à preparação da sua defesa e a comunicar com o advogado da sua escolha; c) A ser julgado num prazo razoável; d) A estar presente no julgamento e a defender-se a si próprio ou por intermédio de um defensor da sua escolha; se não tiver patrocínio jurídico, a ser informado deste direito; e a pedir a designação de um defensor oficioso, sempre que os interesses da justiça exijam a assistência do defensor, sem encargos, se não tiver meios suficientes para os suportar; e) A interrogar ou fazer interrogar as testemunhas de acusação e a obter a comparência e o interrogatório das testemunhas de defesa em condições de igualdade; f) A beneficiar da assistência gratuita de um intérprete se não compreender ou falar a língua utilizada pelo tribunal; g) A não ser obrigado a testemunhar ou a confessarse culpado. 4. No caso de menores, o processo tomará em conta a sua idade e a necessidade de facilitar a sua reintegração social. 5. Os trabalhadores migrantes e os membros das suas famílias condenados pela prática de um crime têm o direito de recorrer dessa decisão para um tribunal superior, nos termos da lei. 6 . Quando uma condenação penal definitiva é ulteriormente anulada ou quando é concedido o indulto, porque um facto novo ou recentemente revelado prova que se produziu um erro judiciário, o trabalhador migrante ou membro da sua família que cumpriu uma pena em virtude dessa condenação será indemnizado, em conformidade com a lei, a menos que se prove que a não revelação em tempo útil de facto desconhecido lhe é imputável no todo ou em parte. Artigo 19 [...] 2. Na determinação da medida da pena, o tribunal atenderá a considerações de natureza humanitária relativas ao estatuto de trabalhador migrante, nomeadamente o direito de residência ou de trabalho reconhecido ao trabalhador migrante ou membro da sua família. (ORGANIZAÇÃO DAS NAÇÕES UNIDAS, 1990).

A seguir, serão abordados os principais óbices processuais de acesso à justiça pelo trabalhador migrante.

\subsection{Idioma e custos do processo}

A primeira barreira fática ao migrante internacional é, sem dúvida, o idioma. O processo judicial brasileiro se desenvolve no idioma nacional, que é a língua portuguesa. A realidade é que não somos um país fluente em línguas estrangeiras, muito pelo contrário. E ainda que assim o

testemunha quando chamada em juízo." (GABINETE DAS NAÇÕES UNIDAS; ALTO-COMISSÁRIO PARA DIREITOS HUMANOS, 2010).

A apreciação pela Câmara dos Deputados sobre a adesão do Brasil à Convenção está parada desde junho de 2015, conforme informação disponível em Câmara dos Deputados (2010). 
fosse, o processo, por se desenvolver perante órgão estatal, precisamente como função típica de um dos poderes do Estado (Poder Judiciário), impõe a prática de atos processuais na língua portuguesa (art. 192, do Código de Processo Civil). Documento redigido em língua estrangeira somente poderá ser juntado aos autos quando acompanhado de versão para a língua portuguesa tramitada por via diplomática ou pela autoridade central, ou firmada por tradutor juramentado (art. 192, parágrafo único, do Código de Processo Civil). O mesmo se aplica ao processo do trabalho, por subsidiariedade (art. 769 da Consolidação das Leis do Trabalho).

Tratando especificamente do processo trabalhista, como melhor explicado adiante, estrutura-se a partir de um procedimento essencialmente oral. Por isso, haverá a necessidade de nomeação de intérprete para a audiência, nos termos do art. 819 da Consolidação das Leis do Trabalho e do art. 162, do Código de Processo Civil, este último aplicável subsidiariamente ao processo do trabalho, respectivamente:

Art. 819. O depoimento das partes e testemunhas que não souberem falar a língua nacional será feito por meio de intérprete nomeado pelo juiz ou presidente. (BRASIL, 1943).

Art. 162. O juiz nomeará intérprete ou tradutor quando necessário para:

I - traduzir documento redigido em língua estrangeira;

II - verter para o português as declarações das partes e das testemunhas que não conhecerem o idioma nacional; [...] (BRASIL, 2015).

Tanto a tradução de documentos estrangeiros para o idioma nacional quanto a nomeação de intérprete, além de representarem inegável acréscimo de tempo de tramitação processual, implicam custos para o processo que o migrante internacional, salvo exceções, não suporta arcar, residindo nesse ponto o segundo óbice para o acesso à justiça.

Além das custas processuais, há a contratação de advogado (assistência técnica), deslocamentos da parte e de suas testemunhas, perícias, traduções e intérprete. São as despesas processuais em sentido amplo, que comportam todos os gastos financeiros, necessários ou úteis para impulsionar o processo e promover a defesa dos interesses da parte.

Evidentemente que esse óbice processual de acesso à justiça é comum também aos nacionais, razão pela qual não se estenderá muito a seu respeito. Para os propósitos deste artigo, que foca nas especificidades do migrante internacional, basta afirmar que é superável por meio da assistência jurídica integral e gratuita, direito fundamental previsto no art. $5^{\circ}$, inciso LXXIV, da Constituição Federal e reproduzido no art. 4, inciso IX, da Lei n. 13.445, de 2017.

No âmbito do processo do trabalho, esse direito fundamental é assegurado de duas formas distintas: por meio da justiça gratuita e da assistência judiciária sindical.

A primeira corresponde à isenção tão somente das custas e emolumentos, e pode ser concedida, de ofício ou mediante requerimento, pelos juízes e órgãos julgadores de qualquer instância e a qualquer tempo no processo, "àqueles que perceberem salário igual ou inferior a 40\% (quarenta 
por cento) do limite máximo dos benefícios do Regime Geral de Previdência Social." (art. 790, \3, da Consolidação das Leis do Trabalho, com a redação conferida pela Lei n. 13.467/2017). ${ }^{6}$

Já a segunda é mais ampla e encontra-se prevista no art. 14, da Lei n. 5.584/70. A assistência judiciária gratuita é devida a todo aquele que perceber salário igual ou inferior ao dobro do mínimo legal, ficando assegurado igual benefício ao trabalhador de maior salário, uma vez provado que sua situação econômica não lhe permite demandar, sem prejuízo do sustento próprio ou da família (BRASIL, 1970). $\mathrm{Na}$ Justiça do Trabalho, portanto, a assistência judiciária é prestada pelos sindicatos a todos os integrantes da categoria profissional. Abrange não somente a isenção de custas, honorários periciais, emolumentos, mas também a assessoria jurídica no curso do processo (assessoria técnica), sendo mais ampla e completa do que a justiça gratuita, consagrada no art. 790, $\$ 3^{\circ}$, da Consolidação das Leis do Trabalho.

Nesse ponto, emerge uma importante consideração a ser feita, especificamente quanto aos refugiados. De acordo com o art. 12, inciso IV, da Lei n. 9474.1997, compete ao Comitê Nacional para os Refugiados (Conare) "orientar e coordenar as ações necessárias à eficácia da proteção, assistência e apoio jurídico aos refugiados." (BRASIL, 1997). No entanto, como destaca a doutrina especializada, ${ }^{7}$ essa atividade de assistência e integração dos refugiados vem sendo desempenhada primordialmente pela sociedade civil, por meio de organizações não governamentais, consistindo a assistência judiciária gratuita na Justiça do Trabalho em mais um ponto de intersecção entre o Estado e a sociedade civil, representada pelos sindicatos. Como escreve Haydu (2011, p. 139-140):

No Brasil, assim como em grande parte do mundo, as políticas para integração de refugiados são empreendidas mediante a inter-relação entre Estado, ACNUR e ONGs, mas, sobretudo, pelas últimas.

No caso brasileiro, a sociedade civil tem assumido papel de grande destaque no trabalho realizado visando à integração de refugiados, fornecendo, por meio de suas atividades diretas ou de parcerias, pouco mais de $60 \%$ do total da verba envolvida nos trabalhos com integração no País.

A Cáritas Arquidiocesana, representante da sociedade civil organizada perante o CONARE, é o ponto focal nesse tema. Vinculada à Igreja Católica, a Cáritas Brasileira atua principalmente em São Paulo e no Rio de janeiro, localidades de maior concentração da população de solicitantes e de refugiados no país (RODRIGUES, 2010: 137-138).

As Cáritas trabalham em três frentes principais, quais sejam, proteção, assistência e integração local. Grande parte deste trabalho é viabilizada por meio de parcerias com entidades de classe, organizações não governamentais, agências internacionais, empresas etc. A parceria com o sistema "S" (SESC, SESI e SENAI), por exemplo, possibilita a inserção de alguns refugiados em cursos profissionalizantes e do idioma português. Casas de passagem, também

\footnotetext{
$\overline{6}$ A Lei n. 13.467/2017 conferiu nova redação ao art. 790, § $3^{\circ}$ da Consolidação das Leis do Trabalho, isentando do pagamento das custas processuais e emolumentos somente aqueles que perceberem como remuneração até $40 \%$ do limite máximo dos benefícios do Regime Geral de Previdência Social. Note-se que a alteração legislativa, a despeito da hipossuficiência do trabalhador, reduziu o benefício da justiça gratuita a patamares aquém dos utilizados no processo civil, no qual, em tese, as partes estão em situação de igualdade.

ISso porque, de acordo com a novel legislação, a mera declaração do requerente da justiça gratuita não será suficiente, ao passo que, no processo civil, o art. 99, $₫ 3^{\circ}$ do Código de Processo Civil, presume "verdadeira a alegação de insuficiência deduzida exclusivamente por pessoa natural", para fins de concessão da gratuidade da justiça que, no processo do trabalho, corresponde à assistência judiciária gratuita.

7 Por exemplo, Sanchez e Mialhe (2017).
} 
conhecidas como albergues, também são importantes parcerias das Cáritas. São elas que propiciam acolhimento temporário a boa parte das pessoas que buscam refúgio no Brasil.

Finalmente, cumpre salientar que a assistência judiciária sindical independe de filiação do trabalhador migrante internacional à agremiação de classe, sendo prestada indistintamente a todos os integrantes da categoria profissional.

\subsection{Prática pessoal de atos processuais e tempo de tramitação}

Como salienta Vedovato (2011, p. 297), invocando Feller (2006, p. 509), "o mundo se alterou e permite que cada vez mais pessoas tenham acesso a informações e a mecanismos para discussão de seus direitos, além do fato de que a mobilidade não pode ser evitada atualmente."

Destarte, a globalização, incrementada pelos avanços tecnológicos e pelos modernos meios de comunicação, reduziu as fronteiras. As pessoas movem-se rapidamente pelos territórios, em fluxos mistos, seja fugindo de perseguições (movimentação forçada), seja em busca de melhores condições de vida (movimentação voluntária).

Certo é que essas pessoas muitas vezes tencionam retornar ao seu país de origem, uma vez cessada a perseguição ou mesmo após um período de trabalho no exterior, para rever parentes ou mesmo recomeçar a vida naquele local, tendo reunido melhores condições financeiras durante o período no exterior. Não é por outro motivo que o art. 42 da "Lei de Refúgio" (Lei n. 9474, de 22 de julho de 1997) prevê como solução duradoura preferencial a repatriação voluntária, a qual corresponde ao retorno ao país de origem, uma vez cessadas as causas da perseguição, que motivaram a concessão do refúgio.

No entanto, essa mobilidade do trabalhador migrante internacional acaba por prejudicar a defesa de seus interesses perante a jurisdição do Estado no qual prestou serviços. $\bigcirc$ processo possui um tempo de tramitação para a prática dos diversos atos processuais que se encontram previamente estruturados em lei, em decorrência do devido processo legal (postulatórios, instrutórios, decisórios e recursais). Ainda fosse o caso de inexistirem "tempos mortos" no processo, aqueles em que o feito permanece aguardando a adequada tramitação pela secretaria ou a prolação de uma decisão pelo juiz, ${ }^{8}$ é invariável que o processo, até assegurar a satisfação do direito material, consuma certo espaço de tempo.

A situação se agrava ainda mais quando o migrante internacional se encontra em situação de permanência irregular no país. As medidas de deportação são expeditas em contraponto ao ritmo lento do processo judicial. Nessa última hipótese, certamente o migrante internacional deixará o país sem defender seus direitos, sem acionar o Judiciário local. Conforme explanado, o migrante em situação irregular é um alvo preferencial de situações de superexploração e de descumprimento da lei trabalhista.

8 Os "tempos mortos" do processo são causados pela falta de estrutura do serviço judiciário, excesso de serviço e despreparo de servidores, entre outros fatores panprocessuais que refogem ao objetivo deste artigo. 
Mas é certo que o migrante internacional, independentemente da regularidade ou não de sua permanência no país, tem direito de ação e de, no curso do processo, defender adequadamente seus interesses. A forma de viabilizar o acesso à justiça, compatibilizando-a com a mobilidade ínsita ao migrante internacional, é a cooperação jurídica internacional, a qual consiste em um princípio e diretriz da política migratória nacional (art. $3^{\circ}$, inciso XV, da Lei de Migração). Regulamentando o instituto, o Código de Processo Civil prevê inclusive a assistência judiciária aos necessitados e viabiliza a propositura de medida judicial em território nacional, por parte do migrante internacional, quando já tenha retornado ao país de origem. Calha transcrever os arts. 26 e 27 do Código de Processo Civil, aplicáveis subsidiariamente ao processo trabalhista:

Art. 26. A cooperação jurídica internacional será regida por tratado de que o Brasil faz parte e observará:

I - o respeito às garantias do devido processo legal no Estado requerente;

II - a igualdade de tratamento entre nacionais e estrangeiros, residentes ou não no Brasil, em relação ao acesso à justiça e à tramitação dos processos, assegurando-se assistência judiciária aos necessitados;

III - a publicidade processual, exceto nas hipóteses de sigilo previstas na legislação brasileira ou na do Estado requerente;

IV - a existência de autoridade central para recepção e transmissão dos pedidos de cooperação;

$\mathrm{V}$ - a espontaneidade na transmissão de informações a autoridades estrangeiras.

$\llbracket 1^{\circ} \mathrm{Na}$ ausência de tratado, a cooperação jurídica internacional poderá realizar-se com base em reciprocidade, manifestada por via diplomática.

$\llbracket 2^{\circ}$ Não se exigirá a reciprocidade referida no $₫ 1^{\circ}$ para homologação de sentença estrangeira.

$\int 3^{\circ} \mathrm{Na}$ cooperação jurídica internacional não será admitida a prática de atos que contrariem ou que produzam resultados incompatíveis com as normas fundamentais que regem o Estado brasileiro.

$\llbracket 4^{\circ} \mathrm{O}$ Ministério da Justiça exercerá as funções de autoridade central na ausência de designação específica.

$[\ldots]$

Art. 27. A cooperação jurídica internacional terá por objeto:

I - citação, intimação e notificação judicial e extrajudicial;

II - colheita de provas e obtenção de informações;

III - homologação e cumprimento de decisão;

IV - concessão de medida judicial de urgência;

$\mathrm{V}$ - assistência jurídica internacional;

VI - qualquer outra medida judicial ou extrajudicial não proibida pela lei brasileira. (BRASIL, 2015).

A cooperação jurídica internacional pode ser ativa (quando o Brasil formula um pedido de cooperação a um Estado estrangeiro) ou passiva (quando o pedido é apresentado no Brasil por um outro Estado). Esse último caso, de cooperação jurídica internacional passiva, é o que tutela a situação dos migrantes internacionais que solicitarão, em seu país de origem, a cooperação ao Estado brasileiro. A também chamada cooperação internacional das jurisdições regula-se por tratado e, na ausência deste, operacionaliza-se por reciprocidade. A tramitação ocorre via autoridade central que, na falta de designação específica, corresponde ao Ministério da Justiça, sendo oportuno destacar que 
seu Departamento de Recuperação de Ativos e Cooperação Jurídica Internacional é a autoridade central para grande parte dos tratados de cooperação jurídica internacional de que o Brasil é parte. ${ }^{9}$

Podem ser objeto de cooperação jurídica internacional uma série de medidas, listadas de modo exemplificativo pelo art. 27 do Código de Processo Civil. E mais: a cooperação jurídica internacional pode ser viabilizada também por meio do auxílio direto, com a possibilidade de propositura de ação judicial trabalhista em território nacional pela autoridade central brasileira, na defesa do direito do estrangeiro. Colhe-se o escólio de Monteiro e Verçosa (2016, p. 132):

Nesse caso, recorde-se, o auxílio direto serve para viabilizar no Brasil o ajuizamento de demanda judicial em favor do Estado estrangeiro - ou, mais frequentemente, em favor de seus cidadãos ou residentes. Essa demanda a ser proposta no Brasil será processada e julgada por juiz brasileiro, sem nenhuma influência ou interferência de juiz estrangeiro. Trata-se, simplesmente, de um processo nacional, como qualquer outro em curso no Poder Judiciário brasileiro, mas como requinte de dizer respeito a interesse de estrangeiro ou cidadão domiciliado no exterior. A demanda poderá ser uma ação cautelar, uma ação de conhecimento, um mandado de segurança, uma ação possessória, uma execução de título extrajudicial, isto é, qualquer tipo de demanda conhecida do ordenamento processual civil brasileiro. Consoante já se afirmou, nada impediria que o cidadão estrangeiro ou residente no exterior contratasse um advogado brasileiro que pudesse representá-lo no Brasil e ajuizar, em seu nome, as ações judiciais cabíveis. Diante, porém, das dificuldades e do custo que essa hipótese poderia acarretar - imagine-se o quão complexo pode ser para um árabe ou um chinês, por exemplo, contratar um advogado no Brasil -, o cidadão estrangeiro ou residente no exterior pode simplesmente dirigir-se à autoridade central brasileira - por meio da autoridade central de seu país - que ela tomará as providências para que a medida de conteúdo jurisdicional seja promovida perante o Poder Judiciário brasileiro. (MONTEIRO; VERÇOSA, 2016, p. 132).

Nesse caso, a autoridade central encaminhará o pedido de auxilio direto à AdvocaciaGeral da União, que requererá em juízo a medida solicitada. Note-se que, nessa hipótese, em que o migrante internacional solicita o auxílio direto para a propositura de ação trabalhista, a assistência jurídica não será prestada pelo sindicato de classe (que fica responsável pela assistência nos demais casos) e sim pela Advocacia-Geral da União, órgão de representação da União.

Cumpre ressaltar que, embora o art. 34 do Código de Processo Civil disponha que compete ao Juízo Federal a apreciação do pedido de auxílio direto passivo que demande prestação jurisdicional, o preceito merece interpretação conforme à Constituição, precisamente o art. 114, inciso I, da Lei Maior, de modo que, quando a situação envolver relação de trabalho encetada em território brasileiro, a competência para essa apreciação é da Justiça do Trabalho, que também é órgão federal. ${ }^{10}$

\footnotetext{
9 Outros órgãos também figuram como autoridades centrais em tratados específicos. Por exemplo, a Procuradoria-Geral da República é a autoridade central na Convenção sobre Prestação de Alimentos no Estrangeiro (ORGANIZAÇÃO DAS NAÇÕES UNIDAS, 1956).

10 Embora o art. 109, III, da Constituição Federal, atribua à Justiça Federal a competência para processar e julgar "as causas fundadas em tratado ou contrato da União com Estado estrangeiro ou organismo internacional", in casu a causa de pedir da ação não é um tratado internacional, mas sim uma relação de trabalho havida no país, o que atrai a competência da Justiça do Trabalho. Saliente-se que a cooperação jurídica internacional poderá se dar também na ausência de tratado internacional, somente com base na reciprocidade. Por esse motivo, não se mostra razoável entender que, na existência de tratado, a Justiça Federal julgaria causa trabalhista, e caso a cooperação internacional se desse com base na reciprocidade, essa competência
} 
Avançando um pouco mais para o momento de tramitação da ação trabalhista, ainda que exista um direito fundamental à razoável duração do processo (art. $5^{\circ}$, LXXVIII, Constituição Federal), também titularizado pelo migrante internacional, a espera não se coaduna com as expectativas do migrante, que acaba, muitas vezes, deixando o país no curso do processo, ainda quando tenha ajuizado a reclamatória trabalhista diretamente em território brasileiro.

No entanto, o processo trabalhista é marcado por uma série de atos que devem ser praticados pessoalmente pelas partes, notadamente o comparecimento pessoal do reclamante na audiência e o depoimento pessoal, sob pena de confissão quanto à matéria de fato. É o que se dessume dos arts. 843, 844 e 848 da Consolidação das Leis do Trabalho (com a redação conferida pela Lei n. 13.467/2017), in verbis:

Art. 843 - Na audiência de julgamento deverão estar presentes o reclamante e o reclamado, independentemente do comparecimento de seus representantes, salvo nos casos de Reclamatórias Plúrimas ou Ações de Cumprimento, quando os empregados poderão fazer-se representar pelo Sindicato de sua categoria.

$\mathbb{1} 1^{\circ}$ - É facultado ao empregador fazer-se substituir pelo gerente, ou qualquer outro preposto que tenha conhecimento do fato, e cujas declarações obrigarão o proponente.

$\int 2^{\circ}$ - Se por doença ou qualquer outro motivo poderoso, devidamente comprovado, não for possível ao empregado comparecer pessoalmente, poderá fazer-se representar por outro empregado que pertença à mesma profissão, ou pelo seu sindicato.

$\int 3^{\circ} \mathrm{O}$ preposto a que se refere o $₫ 1^{\circ}$ deste artigo não precisa ser empregado da parte reclamada.

Art. 844 - O não-comparecimento do reclamante à audiência importa o arquivamento da reclamação, e o não-comparecimento do reclamado importa revelia, além de confissão quanto à matéria de fato.

$\int 1^{\circ}$ Ocorrendo motivo relevante, poderá o presidente suspender o julgamento, designando nova audiência.

$\llbracket 2^{\circ} \mathrm{Na}$ hipótese de ausência do reclamante, este será condenado ao pagamento das custas calculadas na forma do art. 789 desta Consolidação, ainda que beneficiário da justiça gratuita, salvo se comprovar, no prazo de quinze dias, que a ausência ocorreu por motivo legalmente justificável.

$\llbracket 3^{\circ} \mathrm{O}$ pagamento das custas a que se refere o $₫ 2^{\circ}$ é condição para a propositura de nova demanda.

$\int 4^{\circ} \mathrm{A}$ revelia não produz o efeito mencionado no caput se:

I - havendo pluralidade de reclamados, algum deles contestar a ação;

II - o litígio versar sobre direitos indisponíveis;

III - a petição inicial não estiver acompanhada de instrumento que a lei considere indispensável à prova do ato;

IV - as alegações de fato formuladas pelo reclamante forem inverossímeis ou estiverem em contradição com prova constante dos autos.

$\llbracket 5^{\circ}$ Ainda que ausente o reclamado, presente o advogado na audiência, serão aceitos a contestação e os documentos eventualmente apresentados

Art. 848 - Terminada a defesa, seguir-se-á a instrução do processo, podendo o presidente, ex officio ou a requerimento de qualquer juiz temporário, interrogar os litigantes.

seria da Justiça do Trabalho. Deve-se privilegiar, portanto, uma interpretação da norma que não conduza a conclusões contraditórias. 
$\llbracket 1^{\circ}$ - Findo o interrogatório, poderá qualquer dos litigantes retirar-se, prosseguindo a instrução com o seu representante. (BRASIL, 2017).

Isso porque o processo do trabalho é estruturado a partir do princípio da oralidade, que implica a descomplicação do procedimento, a concentração de atos praticados em uma única oportunidade, com a colheita de provas em audiência, através do juiz que tem contato direto com as partes. Pode ser resumido, em linhas gerais, no conceito de simplificação do procedimento e concentração de atos orais.

Mas esse iter procedimental, tecido em princípio para proteger o reclamante e assegurar a celeridade na tramitação do feito, em se tratando de migrante internacional poderá impedir a tutela de seu direito, seja pelo arquivamento de sua ação (em caso de não comparecimento na audiência), seja pela confissão quando à matéria de fato contrariamente aos seus interesses (em razão do não comparecimento em audiência para depor, quando expressamente cominada essa penalidade).

É lição consolidada que o devido processo legal (Art. 5 , inciso LIV, da Constituição da República) impõe que os procedimentos previstos em lei sejam adequados não somente aos direitos por ela tutelados, mas também aos sujeitos que dela vão se valer e aos fins colimados. A respeito da efetividade processual e adequação do procedimento ao direito material, elucidativas as reflexões de Marinoni (2004, p. 188-189):

Será o que o direito à tutela jurisdicional é apenas o direito ao procedimento legalmente instituído, não importando sua capacidade de atender de maneira idônea ao direito material? Ora, não tem cabimento entender que há direito fundamental à tutela jurisdicional, mas que esse direito pode ter sua efetividade comprometida se a técnica processual houver sido instituída de modo incapaz de atender ao direito material. Imaginar que o direito à tutela jurisdicional é o direito de ir a juízo por meio do procedimento legalmente fixado, pouco importando a sua idoneidade para a efetiva tutela dos direitos, seria inverter a lógica entre direito o direito material e o direito processual. Se o direito de ir a juízo restar na dependência da técnica processual expressamente presente na lei, o processo é que dará os contornos do direito material. Mas deve ocorrer exatamente o contrário, uma vez que o primeiro serve para cumprir os desígnios do segundo. Isso significa que a ausência de técnica processual adequada para certo caso conflitivo concreto representa hipótese de omissão que atenta contra o direito fundamental à efetividade da tutela jurisdicional.

Nessa hipótese, a despeito do rito estruturado pela legislação processual trabalhista, deverá o juiz, como diretor do feito, afastar previamente a necessidade de comparecimento pessoal do reclamante, dando ciência antecipada às partes, aplicando o disposto no art. 765 da Consolidação das Leis do Trabalho, que lhe concede ampla liberdade na direção do processo: "Art. 765 - Os Juízos e Tribunais do Trabalho terão ampla liberdade na direção do processo e velarão pelo andamento rápido das causas, podendo determinar qualquer diligência necessária ao esclarecimento delas." (BRASIL, 1943).

Insta salientar que, recentemente, o Novo Código de Processo Civil importou do processo trabalhista a diretiva da ampla liberdade do juiz na condução do processo, cunhando-a de adaptabilidade ou adequação do processo, como um subprincípio da efetividade processual. 
A adaptabilidade ou adequação do processo apregoa que o processo deve ser estruturado em atenção às especificidades da causa, sejam de cunho subjetivo (por exemplo, prazo em dobro para pessoa jurídica de direito público ou mesmo a situação do migrante internacional), finalístico (objetivo que se visa alcançar, por exemplo, diferenças procedimentais entre a fase de conhecimento e a fase de cumprimento) ou objetivo. Quanto ao critério objetivo, leciona Didier Júnior (2015, p. 116):

Três são, basicamente, os critérios objetivos de que se vale o legislador para adequar a tutela jurisdicional pelo procedimento: um, a natureza do direito litigioso, cuja relevância impõe uma modalidade de tutela diferenciada; o segundo, a evidência como se apresenta o direito material no processo; o terceiro, a situação processual de urgência.

E no caso de ausência de procedimento adequado estruturado normativamente para a tutela do direito, cabe ao órgão jurisdicional efetuar a adequação, sempre precedida de uma intimação às partes para que se manifestem sobre a pretendida adaptação do procedimento, providência essa que objetiva salvaguardar o contraditório prévio, impedindo "decisões-surpresa".

Poder-se-ia objetar que, especialmente no que tange ao depoimento pessoal do reclamante, esse ato processual poderia ser realizado via cooperação jurídica internacional, o que, em princípio, revela-se viável. No entanto, tal medida parece contraprodutiva, pois alargaria em demasia o tempo de tramitação processual e oneraria financeiramente o processo, sem ganho significativo para causa, pois a oitiva das partes, tirante a hipótese de obtenção de confissão, em regra, pouco contribui para o descobrimento da verdade, justamente em razão da parcialidade do declarante. Assim, como regra, essa opção somente deverá ser aceita quando for a única alternativa viável como meio de prova.

Outrossim, moldando-se o procedimento à necessidade de justa pacificação do conflito, de modo atento às especificidades da causa, prestigia-se o princípio protetor, norte também do processo do trabalho, o que também se coaduna com a natureza alimentar do crédito trabalhista.

\section{Acordo de Cooperação e Assistência Jurisdicional}

Para contextualizar o quanto sustentado, vale discorrer, ainda que brevemente, sobre o conteúdo do Acordo de Cooperação e Assistência Jurisdicional em Matéria Civil, Comercial, Trabalhista e Administrativa entre os Estados-Partes do Mercosul, a República da Bolívia e a República do Chile, promulgado entre nós pelo Decreto n. 6.891/2009.

Referido instrumento internacional, que entrou em vigor para o Brasil, no plano jurídico externo, em 08 de fevereiro de 2009, foi selecionado por razões empíricas: a presença maciça em território nacional de migrantes internacionais oriundos desses países, notadamente bolivianos, o que incrementa as chances de sua aplicação prática.

O acordo regula a cooperação em atividades de simples trâmite processual ou em atividades probatórias. É o que disciplina o art. $5^{\circ}$ : 
Cada Estado Parte deverá enviar às autoridades jurisdicionais do outro Estado Parte, segundo o previsto nos artigos 2 e 10, carta rogatória em matéria civil, comercial, trabalhista ou administrativa, quando tenha por objeto:

a) diligências de simples trâmite, tais como citações, intimações, citações com prazo definido, notificações ou outras semelhantes;

b) recebimento ou obtenção de provas.

mesmo instrumento ainda preceitua que as cartas rogatórias poderão ser transmitidas por via diplomática ou consular, por intermédio da respectiva autoridade central ou pelas partes interessadas, em conformidade com o direito interno. Caso a transmissão da carta rogatória seja efetuada por intermédio das autoridades centrais ou por via diplomática ou consular, não se exigirá o requisito da legalização. Caso seja transmitida por intermédio da parte interessada, deverá ser legalizada pelos agentes diplomáticos ou consulares do Estado requerido, salvo se entre o Estado requerente e o requerido tiver sido suprimido o requisito da legalização ou substituído por outra formalidade (art. 10).

Observe-se, assim, que mesmo entre os países-membros do Mercado Comum do Sul (Mercosul) e alguns dos seus Estados associados (Chile e Bolívia), em que há maior integração e um fluxo considerável de migrantes internacionais, adotou-se no âmbito internacional o modelo-padrão para operacionalizar o trâmite processual em território estrangeiro, qual seja, a carta rogatória, modalidade de comunicação processual de longa data conhecida no direito nacional, mas de difícil utilização em razão do trâmite entre as jurisdições, o que consome considerável tempo e recursos e, portanto, acaba retardando a solução do processo.

Evidentemente que o quanto sustentado neste artigo não afasta a possibilidade de utilização do instrumento internacional no caso concreto, operacionalizando-se a cooperação entre as jurisdições por meio da rogatória. No entanto, conforme explanado, a legislação nacional, ressalvado o caso de propositura de ação por migrante internacional que já deixou o território nacional, quando será imprescindível a cooperação jurídica internacional nos moldes do acordo internacional ou com base na reciprocidade, contempla mecanismos que, salvo melhor juízo, são mais eficazes para o mesmo desiderato de assegurar o acesso à justiça ao migrante internacional, com maior economia de tempo e de dinheiro, o que deve conduzir à sua utilização preferencial.

\section{Conclusão}

Os migrantes ocupam uma posição marginalizada, tanto em termos de identidade cultural e social, quanto no sentimento de não pertencimento a sua nova comunidade, onde, frequentemente, desponta a xenofobia e a intolerância.

Várias ainda são as barreiras processuais para a defesa dos direitos do trabalhador migrante internacional perante Justiça do Trabalho. 
Entretanto, os óbices de ordem cultural (idioma), econômica (custos do processo), tempo de tramitação do processo e a obrigatoriedade da prática pessoal de determinados atos processuais devem ser superados em prol do direito fundamental ao devido processo legal em sua acepção mais moderna (art. $5^{\circ}$, inciso LIV, da Constituição Federal).

O primeiro passo para essa defesa, inclusive em juízo, é a informação, o esclarecimento ao trabalhador migrante sobre seus direitos e as condições nas quais se desenvolve um processo judicial em território nacional para que este, juridicamente assessorado, possa tomar uma decisão informada.

Para além de proclamação formal de direitos de cunho trabalhista aos migrantes internacionais, impõe-se sua efetivação prática, o que se viabiliza, entre outros, por intermédio do direito de ação, o qual deve se desenvolver em um processo justo e equilibrado. Para tanto, é preciso interpretar e aplicar o direito instrumental de ação e o próprio processo e seus modelos de tramitação de forma consentânea com as particularidades jurídicas e fáticas do trabalhador migrante, sendo indispensável conhecer, simultaneamente, a condição do migrante e também as normas processuais que podem favorecer ou dificultar a defesa de seus direitos, para uma tutela adequada.

$\bigcirc$ grande desafio que se coloca atualmente, em termos de direitos fundamentais, é a sua efetivação. Não se deve esquecer que o que diferencia o Direito da Moral é justamente a sua coercitibilidade. A possibilidade de garantir os direitos fundamentais de ataques recorrentes se viabiliza, na prática, por meio do direito de ação.

Impende aprimorar os mecanismos processuais existentes para que possam dar cobro das mais diversas situações, servindo de efetivo instrumento para a tutela de direitos. $O$ direito de ação e de efetividade processual, como direitos fundamentais de caráter acessório, não devem ser meras declarações formais de direitos que, na prática, são de pouca ou nenhuma valia.

\section{Referências}

ALTO COMISSARIADO DAS NAÇÕES UNIDAS PARA REFUGIADOS. Convenção Sobre o Estatuto dos Refugiados (1951). Disponível em: <http://www.acnur.org/t3/fileadmin/Documentos/portugues/BDL/Convencao_relativa_ao_Estatuto_dos_Refugiados.pdf>. Acesso em: 06 abr. 2017.

ALTO COMISSARIADO DAS NAÇÕES UNIDAS PARA REFUGIADOS. Declaração de Cartagena. Adotada pelo "Colóquio sobre Proteção Internacional dos Refugiados na América Central, México e Panamá: Problemas Jurídicos e Humanitários", realizado em Cartagena, Colômbia, entre 19 e 22 de Novembro de 1984. Disponível em: <http://www.acnur.org/t3/fileadmin/Documentos/portugues/BD_Legal/Instrumentos_Internacionais/Declaracao_de_Cartagena.pdf $>$. Acesso em: 06 abr. 2017.

ALTO COMISSARIADO DAS NAÇÕES UNIDAS PARA REFUGIADOS. Estatísticas do ACNUR mostram aumento alarmante de violência sexual na RDC. ONUBR, 30 jul. 2013. Disponível em: <http://www.acnur.org/portugues/recursos/estatisticas/>. Acesso em: 06 abr. 2017. 
ALTO COMISSARIADO DAS NAÇÕES UNIDAS PARA REFUGIADOS. Protocolo de 1967 Relativo ao Estatuto dos Refugiados. Disponível em: <http://www.acnur.org/t3/fileadmin/Documentos/portugues/BDL/Protocolo_de_1967_Relativo_ao_Estatuto_dos_Refugiados.pdf >. Acesso em: 06 abr. 2017.

BAUMAN, Zygmunt. Estranhos à nossa porta. Rio de Janeiro: Zahar, 2017.

BOBBIO, Norberto. A Era dos Direitos. Rio de Janeiro: Campus, 1992.

BRASIL. Constituição. República Federativa do Brasil de 1988. Brasília, DF: Senado Federal, 08 out. 1988. Disponível em: < http://www.planalto.gov.br/ccivil_03/constituicao/constituicao.htm>. Acesso em: 06 abr. 2017.

BRASIL. Decreto-Lei n. 5.452, de $1^{\circ}$ de maio de 1943. Aprova a Consolidação das Leis do Trabalho. Diário Oficial da União, Brasília, DF, 02 maio 1943. Disponível em: <http://www.planalto.gov.br/ ccivil_03/decreto-lei/Del5452compilado.htm >. Acesso em: 06 abr. 2017.

BRASIL. Decreto n. 58.819, de 14 de julho de 1966. Promulga a Convenção 97 sobre Trabalhadores Migrantes. Diário Oficial da União, Brasília, DF, 15 jul. 1966. Disponível em: <http://www.planalto.gov.br/ccivil_03/decreto/1950-1969/D58819.htm>. Acesso em: 06 abr. 2017.

BRASIL. Decreto n. 6.891, de 02 de julho de 2009. Promulga o Acordo de Cooperação e Assistência Jurisdicional em Matéria Civil, Comercial, Trabalhista e Administrativa entre os Estados Partes do Mercosul, a República da Bolívia e a República do Chile. Diário Oficial da União, Brasília, DF, 03 jul. 2009. Disponível em: <http://www.planalto.gov.br/ccivil_03/_ato2007-2010/2009/decreto/d6891. htm >. Acesso em: 06 abr. 2017.

BRASIL. Lei n. 13.015, de 16 de março de 2015. Código de Processo Civil. Diário Oficial da União, Brasília, DF, 17 mar. 2015. Disponível em: <http://www.planalto.gov.br/ccivil_03/_ato20152018/2015/lei/113105.htm >. Acesso em: 06 abr. 2017.

BRASIL. Lei n. 13.445, de 24 de maio de 2017. Institui a Lei de Migração. Diário Oficial da União, Brasília, DF, 25 maio 2017. Disponível em: <http://www.planalto.gov.br/ccivil_03/_ato20152018/2017/lei/L13445.htm >. Acesso em: 06 abr. 2017.

BRASIL. Lei n. 5.584, de 26 de junho de 1970. Dispõe sobre normas de Direito Processual do Trabalho, altera dispositivos da Consolidação das Leis do Trabalho, disciplina a concessão e prestação de assistência judiciária na Justiça do Trabalho, e dá outras providências. Diário Oficial da União, Brasília, DF, 27 jun. 1970. Disponível em: <http://www.planalto.gov.br/ccivil_03/leis/L5584.htm>. Acesso em: 06 abr. 2017.

BRASIL. Lei n. 6.815, de 19 de agosto de 1980. Define a situação jurídica do estrangeiro no Brasil, cria o Conselho Nacional de Imigração. Diário Oficial da União, Brasília, DF, 20 ago. 1980. Disponível em: <http://www.planalto.gov.br/ccivil_03/leis/L6815.htm>. Acesso em: 06 abr. 2017.

BRASIL. Governo prorroga visto humanitário para haitianos. Governo do Brasil, 14 set. 2016. Disponível em: <http://www.brasil.gov.br/cidadania-e-justica/2016/09/governo-prorroga-visto-humanitario-para-haitianos>. Acesso em: 06 abr. 2017. 
BRASIL. Lei n. 9.474, de 22 de julho de 1997. Define mecanismos para a implementação do Estatuto dos Refugiados de 1951, e determina outras providências. Diário Oficial da União, Brasília, DF, 23 jul. 1997. Disponível em: <http://www.planalto.gov.br/ccivil_03/leis/L9474.htm>. Acesso em: 06 abr. 2017.

CÂMARA DOS DEPUTADOS. MSC 696/2010. Submete à consideração do Congresso Nacional texto da Convenção Internacional sobre a Proteção dos Direitos de Todos os Trabalhadores Migrantes e dos Membros das suas Famílias, adotada em 18 de dezembro de 1990, em Sessão da Assembléia Geral das Nações Unidas. 15 out. 2010. Disponível em: <http://www.camara.gov.br/proposicoesWeb/fichadetramitacao? idProposicao=489652 > . Acesso em: 17 jan. 2018.

DIDIER JÚNIOR, Fredie. Curso de Direito Processual Civil. Introdução ao Direito Processual Civil, Parte Geral e Processo de Conhecimento. 17. ed. Salvador: JusPodivm, 2015. v. 1.

FELLER, Erika. Asylum, migration and refugee protection: realities, myths and the promise of things to come. International Journal of Refugee Law, v. 18, i. 3-4, p. 509, 2006.

GABINETE DAS NAÇÕES UNIDAS; ALTO-COMISSÁRIO PARA DIREITOS HUMANOS. Convenção Internacional sobre Trabalhadores Migrantes e seu Comitê. Boletim Informativo n ${ }^{\circ} 24$ (Rev. 1). Brasília, 13 dez. 2010. Disponível em: <http://www.camara.gov.br/proposicoesWeb/prop_mostrarintegra; jsessionid =7E31BBA1C844521E6EB1ACDE5836463C. proposicoesWebExterno2? . codteor $=917816 \&$ filename $=$ MSC $+696 / 2010>$. Acesso em: 17 jan. 2018.

HAYDU, Marcelo. A integração dos refugiados no Brasil. In: RAMOS, André de Carvalho; RODRIGUES, Gilberto; ALMEIDA, Guilherme Assis de (Org.). 60 Anos de ACNUR. Perspectivas de futuro. São Paulo: ACNUR/Editora CL-A Cultural, 2011. p. 131-145.

KANT, Immanuel. À paz perpétua. Tradução e prefácio Marco Zingano. Porto Alegre: L\&PM, 2008.

MARINONI, Luiz Guilherme. Teoria Geral do Processo. 6. ed. São Paulo: RT, 2012.

MARINONI, Luiz Guilherme. Técnica Processual e Tutela de Direitos. São Paulo: RT, 2004.

MIALHE, Jorge Luís. A naturalização dos refugiados. In: SÁNCHEZ BRAVO, Alvaro; MIALHE, Jorge Luís (Org.). Refugiados e migrações no século XXI: direitos fundamentais e relações internacionais. Belo Horizonte: Arraes, 2017. p. 49-60.

MONTEIRO, André Luís; VERÇOSA, Fabiane. Comentários aos Artigos 26 e 34 do Novo Código de Processo Civil. - Título II. Capítulo II. A Cooperação Jurídica Internacional. In: WAMBIER, Teresa Arruda Alvim et al. (Coord.). Breves Comentários ao Novo Código de Processo Civil. 3. ed. São Paulo: RT, 2016. p. 133-157.

ORGANIZAÇÃO DAS NAÇÕES UNIDAS. Número de migrantes internacionais chega a cerca de 244 milhões, revela ONU. ONUBR, 13 jan. 2016. Disponível em: < https://nacoesunidas.org/numero-de-migrantes-internacionais-chega-a-cerca-de-244-milhoes-revela-onu/ $>$. Acesso em: 06 abr. 2017. 
ORGANIZAÇÃO DAS NAÇÕES UNIDAS. Convenção Internacional sobre a Proteção dos Direitos de Todos os Trabalhadores Migrantes e dos Membros das suas Famílias. Adotada pela Resolução 45/158 da Assembléia Geral da ONU em 18 de dezembro de 1990. Disponível em: <http://acnudh.org/ wp-content/uploads/2012/08/Conven\%C3\%A7\%C3\%A3o-Internacional-para-a-Prote\%C3\%A7\%C3\%A3o-dos-Direitos-Humanos-de-todos-os-Trabalhadores-Migrantes-e-Membros-de-suas-Fam\%C3\%ADlias.pdf>. Acesso em: 06 abr. 2017.

ORGANIZAÇÃO INTERNACIONAL DO TRABALHO. C-143 - Convenção Sobre as Imigrações Efetuadas em Condições Abusivas e Sobre a Promoção da Igualdade de Oportunidades e de Tratamento dos Trabalhadores Migrantes. Disponível em: <http://www.ilo.org/brasilia/convencoes/ WCMS_242707/lang--pt/index.htm >. Acesso em: 06 abr. 2017.

ORGANIZAÇÃO INTERNACIONAL PARA MIGRAÇÕES. IOM Definition of "Migrant". Disponível em: <https://www.iom.int/who-is-a-migrant>. Acesso em: 17 jan. 2018.

ORGANIZAÇÃO INTERNACIONAL PARA MIGRAÇÕES. World Migration Report 2018. Genebra: IOM, 2017. Disponível em: <https://publications.iom.int/system/files/pdf/wmr_2018_en.pdf>. Acesso em: 17 jan. 2018.

PARDI, Luís Vanderlei. O regime jurídico da expulsão de estrangeiros no Brasil: uma análise à luz da Constituição Federal. São Paulo: Almedina, 2015.

SANCHEZ BRAVO, Alvaro; MIALHE, Jorge Luís (Org.). Refugiados e migrações no século XXI: direitos fundamentais e relações internacionais. Belo Horizonte: Arraes, 2017.

SÃO PAUlO (Estado). Habeas Corpus n. 94016 MC/SP. Relator: Min. Celso de Mello. Julgamento em 07 abr. 2008. Disponível em: <http://stf.jus.br/portal/processo/verProcessoAndamento. asp? numero $=94016 \&$ classe $=$ HC\&codigoClasse $=0$ \&origem $=J U R \&$ recurso $=0 \&$ tipoJulgamento $=M>$. Acesso em 06 abr. 2017.

SARLET, Ingo Wolfgang. A Eficácia dos Direitos Fundamentais. 9. ed. Porto Alegre: Livraria do Advogado, 2007.

STANDING, Guy. O precariado: a nova classe perigosa. São Paulo: Autêntica, 2013.

VEDOVATO, Luís Renato. O direito dos refugiados e realidade: a necessária diminuição das distâncias entre o declarado e o alcançado. In: RAMOS, André de Carvalho; RODRIGUES, Gilberto; ALMEIDA, Guilherme Assis de (Org.). 60 Anos de ACNUR. Perspectivas de futuro. São Paulo: ACNUR/Editora CL-A Cultural, 2011. p. 289-312.

Data da submissão: 02 de fevereiro de 2018 Avaliado em: 13 de abril de 2018 (AVALIADOR A) Avaliado em: 15 de maio de 2018 (AVALIADOR C) Aceito em: 28 de junho de 2018 
